\title{
The changing role of European Documentation Centres and how 'Brexit' might affect the network
}

\author{
Author: \\ Margaret Watson \\ Academic Services Librarian \\ Bodleian Law Library \\ St Cross Building \\ Manor Road \\ OXFORD \\ OX1 3UR
}

\section{Biography}

Margaret Watson is the Academic Services Librarian in the Bodleian Law Library, Oxford. She has worked in the field of EU information for over 25 years, starting out as the EDC Librarian at the University of Exeter in 1983. She then worked for nearly ten years in the City of London, where she was responsible for monitoring EU information in the Brussels and London offices of law firm Lovell, White \& King (subsequently Lovell White Durrant). She joined the Bodleian Library in 1996, and was put in charge of the University of Oxford EDC when she took up her present post, in 2001.

\footnotetext{
Abstract

European Documentation Centres (EDCs) are neutral collections of official publications of the European Union, open to the public and normally housed in academic institutions throughout the European Union (EU). EDC status entitles the host organisation to receive one copy of the most significant publications and documents of the EU. The EDC network goes back to 1963, and its primary purpose has always been the support of academic research into European integration. The decision to trigger Article 50 of the Treaty on European Union clearly raises questions about role of the EDCs in the United Kingdom after 'Brexit'.
} 


\section{The changing role of European Documentation Centres and how 'Brexit' might affect the network}

\section{Introduction}

The UK has thirty-two European Documentation Centres (EDCs)', located, for the most part in academic libraries, which form part of a wider network of EDCs and other information centres (or 'Relays') covering the twenty-eight member states of the European Union. The EDC network is unique among these Relays firstly in that it has an academic remit and secondly for the fact that EDCs are politically neutral; promoting the EU is not one of their functions. While the ways in which EDCs function vary according to the practices and purpose of their host institutions, from the start there has been a focus on the dissemination of publications: originally, all EDCs automatically received, free of charge, one printed copy of most EU periodical and monograph publications. These official publications contained information ranging from policy developments in all areas of EU activity, to statistics on trade, demographics, agriculture, transport, energy and economic indicators. The EDC network was originally aimed at ensuring traditional library provision of printed resources to academics. The material was only available in hard copy, and readers almost always actually came to the EDCs to use it. The EU's side of the partnership was to provide the publications; the libraries' side was primarily to make the publications available to the academic community, and sometimes also to the public. This meant that the libraries took on all the administrative tasks of accessioning, cataloguing, boxing, shelving, and so on, as well as answering enquiries. In other words, the host institution offered the staff, the skills, the space and the technology to manage a collection of printed material that was provided by the European Commission.

\section{The evolving role of EDCs}

Over the years there has been some ambiguity and confusion regarding the role of the network. EDCs are supported by the European Commission (they currently fall under the auspices of DG Communication), under the terms of an agreement between the Commission and the host institution. Richard Caddel, writing in 1997, noted that 'Very little of the EDC's early work was defined or monitored ... if there was an initial contract governing EDC's purpose, few EDC librarians saw it." ${ }^{\prime i i}$ However it is clear from evidence provided by lan Thomson, writing in 1990, that 'EDCs were not set up to provide an information service to the general public or to any specialist group other than the academic. ${ }^{\text {iii }}$

Over the years, the partnership arrangement between the European Commission and the host institutions has not always been straightforward, as the Commission has also sought to use EDCs as vehicles for the dissemination of information to the general public. The first agreement between the Commission and the EDCs' host institutions was introduced in 1994, and has since been updated.

Article 4.2 of the Rules annexed to the current EDC Agreement specifies that one of the objectives of the EDC is to 'make information on the European Union and its policies available to the public, both University-based and other'. The shifting position over the years as to whether EDCs are intended to support academic research or to fulfil an additional wider information provision function is illustrated by the thoroughly confusing sequence of changes in responsibility for the network that has taken place within the European Commission itself. According to contemporary secondary sources, first the network was transferred within DGX from the Higher Education Office to the Information Networks and Relays Unit (INRU), iv subsequently moving from INRU to Education and Culture, ${ }^{v}$ before responsibility for EDCs within the Commission was transferred from DG Education

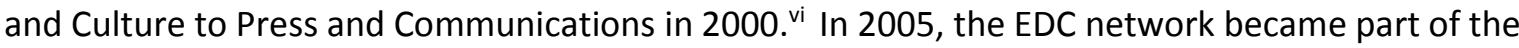


Europe Direct information network, managed by unit B.2 within DG Communication (formerly DG PRESS/A.2) and from January 2007, management of EDCs in non-EU countries was transferred to DG External Relations and DG Enlargement. vii

\section{EDCs and their host institutions}

So far, I have written about the partnership between the EU and the European Commission, but in the UK there is also a partnership within each host institution between the academic departments and the library that houses the EDC. Each EDC has its own unique character. For example the situations of the two EDCs that I have managed, at the University of Exeter in the 1980s and in the Bodleian Law Library since 2001, could hardly have differed from each other more greatly. At Exeter, the EDC was closely associated with, and housed in the same building as, its primary academic department, the Centre for European Legal Studies. Indeed the association was so close that all publications came addressed to the professor who directed the Centre, and were not addressed to the Library at all. Even my salary, I learned, was derived from money originally intended to provide the professor with secretarial support, and although the EDC was in fact an integral part of the Exeter University Library, the Director of the Centre in some ways also acted as the director of the EDC. Despite the fact that the Library was independent of the Faculty, the Faculty members regarded it very much as their own resource. This arrangement, as it was understood by the Faculty, would possibly have seemed entirely natural in continental Europe, and although it did not conform to the administrative reality of the University it was in some ways highly beneficial. The close link between the EDC and the Faculty was strengthened by the fact that, in those days, researchers had to come to the Library even to use the catalogue, let alone to access the documentation, and so I knew them all, and I understood their areas of interest and could support their research. They taught me about the content of the documentation, and as I became the first person to read the Official Journal each day, I remember being asked to look out for specific items, such as the publication of a Protocol to the Judgments Convention in the $\mathrm{C}$ series of the Official Journal.

\section{The impact of electronic publishing on EDCs}

This was all before the development of the internet. The situation today is very different: thirty years on, the electronic delivery of documents has radically changed the nature of EDCs. Over time, the monthly list of the publications delivered free of charge from Luxembourg dwindled, first from being several sheets in length to less than a page, and then was finally abandoned all together. The move from print to electronic provision has changed the relationship between the EDC and the academic community. At the time that I was put in charge of the EDC in the Bodleian in 2001, there were already anxious discussions among EDC librarians about what the future held for their (increasingly online) collections. Oxford was, of course, different to Exeter. The whole organisation of the University, with its collegiate structure meant that the academic staff of the Law Faculty didn't generally work together in one building as they did in Exeter. But even had they done so, by 2001 they would not have needed to come to the Library to consult the catalogue. In March 2000, the free distribution of the printed Official Journal to EDCs had ceased, and by September 2001, EDCs had also been invited to cease taking COM documents in print, on the grounds that they were available on Web. viii Today researchers expect to access the majority of recent EU documentation online, but previously, access to the printed documents was vital for research; indeed, in the early years, there was some competition to house Oxford's EU documentation, with St Antony's college apparently considering putting in a bid to become an EDC. The College's arguments were forcefully rebutted by Stephen Richard, the Bodleian's Official Papers librarian in an internal memo, $(16 / 10 / 1977)$, in which he pointed out that 'The Bodleian, as a depository for European 
Communities publications, is entitled to receive a greater range of materials than an EDC; so has a greater potential for research'. It is hard to imagine such competition to house an EDC taking place today.

\section{Print versus electronic holdings in EDCs}

Under the original agreement made by exchange of letters in 1963, the Bodleian became, as Stephen Richard noted, a 'Depository Library', and it has continued to keep all 'the publications of the various Community institutions' that have been dispatched to it since January 1964 . $^{\text {ix }}$ That status seems at some point to have changed from 'Depository Library' to 'EDC', ' but the Oxford EDC has nevertheless retained all its print holdings, although the collection now grows very slowly. Other EDCs have disposed of some print collections, and this, together with the fact that very little is now provided in print, begs the question, 'what is an EDC and what is the role of an EDC librarian if the resources are largely electronic?'. Delegates to the annual EDC meetings hosted by the Commission's UK Representation during the first decade of this century, spoke of fewer readers using their collections and of reduced numbers of enquiries, but considered on the other hand, that those enquiries that did come through were typically more complex than they had been in the past. Readers were clearly beginning to find their way around the online resources, but still consulting the librarian when they got stuck, sometimes at quite an advanced point in their investigations; in my experience, this pattern of enquiries is still the case..$^{\mathrm{xi}}$ It also remains a fact that not everything is freely available online. For example, I remember one extremely experienced researcher who arrived with a detailed list of documents related to the Phare programme that she needed to track down; having already exhausted the online resources, she needed to fill the gaps by consulting our paper and microfiches collections. Further, even if the material is online, it is not always easy to find or interpret, and I have spent afternoons with researchers helping them to sort out which legislation was in force at particular times, or tracking down citations for them in order to check references in a draft for publication.

\section{EDCs as centres of expertise; EDC librarians and democratic legitimacy}

Grace Hudson, currently Chair of the European Union Databases User Group, put the question well in the early 2000s when she asked at an EDC AGM: 'If your library was not an EDC, would it still be a centre of expertise on EU information?'. It is significant that EDC Agreement, signed by the Commission and the host institution, and updated over the years, has always required a professional librarian to be placed in charge of the EDC. ${ }^{\text {xii }}$ This requirement is key to both the efficient and effective operation of the EDC as a research resource, and to its role as a source of politically unbiased information. The first point, regarding efficiency and effectiveness, is self-evident. To take the second point, although professional librarians are not tightly regulated, as qualified staff, we are subject to both the ethical restraints of both our profession ${ }^{\text {xiii }}$ and those of the institutions for which we work. Cyril Emery, speaking at the United Kingdom's 2008 EDC Annual Conference (14 January 2008), argued that the fact that EDCs are managed by professional staff, who are paid by their host institution and not by the European Commission, gives them a particular value as providers of information on the EU. Unlike the Commission's other information networks, EDCs, because of their independence, clearly do not distribute propaganda, and elsewhere Emery has suggested that EDC librarians 'have a unique potential to provide legal transparency in the European Union and thus strengthen its democratic legitimacy' ${ }^{\text {xiv }}$

\section{The role of EDC librarians post-'Brexit'}


In 2008 (long before the Referendum), Emery's argument strongly supported the value of EDC librarians to the EU as 'agents of legal transparency', but how relevant would this role be in a post'Brexit' information environment? Further, could this function be, in itself, sufficient reason for the European Commission to continue to support the UK's EDCs? Possibly not, but the UK's EDCs will not suddenly cease to be centres of expertise after March 2019, and it is to be hoped that the EU will continue to recognise their value. From the start, EDCs were established in countries that were not members of the EU, and collections of EU documentation were made available in countries such as the USA that were obviously never going to apply for EU membership. There can be no doubt that 'Brexit' will be a fertile field for academic research and that University staff will continue to need the support of librarians who understand EU documentation. Whatever form 'Brexit' takes, there will be legal developments and consequences that spring from it. While these may be pursued through legislation and litigation, academic librarians will have a significant role to play in identifying, collecting, organising and making accessible the full range of documentation, not just that which is relevant to a particular legal case or point of view. Moreover, the UK EDCs that are established in some of our national and academic libraries are hosted by institutions that have a stability that enables them to take the long view not only considers immediate needs but also anticipates future research requirements.

\section{EDC librarians' contribution to the organisation and dissemination of EU information}

Over the years, the EDC network, with support from the EU in the form of training, networking activities, and access to the officials of the EU Institutions and the national representations, has provided a bedrock on which expertise in EU documentation has grown. This manifests itself in teaching resources, such as the EU section of the BIALL Legal Research Training Pack, which is largely the work of an EDC librarian, and in networks such as the European Union Databases User Group https://eudatabaseusergroup.wordpress.com/ which is chaired by former national EDC Co-ordinator Grace Hudson. Current and former UK EDC librarians have published bibliographies and guides to EU documentation, that range from John Jeffries' A guide to the Official Publications of the European Communities, through lan Thomson's The Documentation of the European Communities: A Guide, to Patrick Overy's European Union information: A Guide to Official Sources. It was as a result of contacts made between the Bodleian and British Library EDCs and EU officials, at a seminar for EDC and other network managers, that the Bodleian has followed the British Library's lead and imported the records of EU Bookshop into its search and discovery tool, SOLO http://solo.bodleian.ox.ac.uk/. UK EDC librarians have also led the way in developing training in the use of EU documentation, notably in the past through the now disbanded European Information Association, but also more recently on behalf of organisations such as BIALL and the Association for Information Management (ASLIB). Cardiff EDC Librarian lan Thomson has been the driving force behind the free online resource European Sources Online (ESO) http://www.europeansources.info/ which developed from European Access, the bibliographic service that he created in the 1980s, and which is now published by Cardiff University Press as an activity of the Cardiff EDC within the University Library Service.

\section{Conclusion}

'Brexit' is certainly a threat to the UK EDCs. In particular, we risk losing our privileged access to EU officials and a weakening of our international ties with other professional librarians working in the field of EU information. However it also presents a huge opportunity, offering a spur to academic research, increased demand for access to EU documentation, and a new relevance for both our collections and our professional expertise.

\section{Bibliography}


Bell M and Watson M, 'European Documentation Centres: Providing Researchers with a Way through the Maze' (2009) 9 Legal Information Management 104

Caddel R, 'European documentation centres: The development of a UK information relay' (1997) 24 Journal of Government Information 103

Emery C, 'The Democratic Function of EDC Librarian's (2008) Focus: News and Views from the European Information Association (8) 1. Available at SSRN: https://ssrn.com/abstract=2051305 Accessed 02/07/2017

Jeffries J, A Guide to the Official Publications of the European Communities (2nd edn, Mansell 1981)

Overy P, European Information: A Guide to Official Sources. (EIA 2005)

Overy P and Mayfield I, 'Documentation of the European Union in 2000' (2001) 39 Journal of Common Market Studies 183

Sargent C, Parker S and Marcella R, 'The Provision of European Information to the Academic Community in University Libraries: A Case Study of a European Documentation Centre' (2000) 101 New Library World 161

Thomson I, 'European Documentation Centres: Their Role in EC Information Provision, with Particular Reference to the United Kingdom' (1990) 17 Government Publications Review (2)107

Thomson I, The Documentation of the European Communities: A Guide (Mansell 1989)

\footnotetext{
'This number is twelve fewer than the forty-four EDCs noted by Richard Caddel in 1997: Richard Caddel, 'European Documentation Centres: The Development of a UK Information Relay' (1997) 24 Journal of Government Information 103.

ii Caddel (ni).

iii Ian Thomson, 'European Documentation Centres: Their Role in EC Information Provision, with Particular Reference to the United Kingdom' (1990) 17 Government Publications Review (2)107.

iv Caddel (ni).

${ }^{\vee}$ Claire Sargent, Susan Parker and Rita Marcella 'The Provision of European Information to the Academic Community in University Libraries: A Case Study of a European Documentation Centre' (2000) 101 New Library World 161.

vi Patrick Overy and Ian Mayfield, 'Documentation of the European Union in 2000' (2001) 39 Journal of Common Market Studies 183.

vii Commission, 'Internal Guidelines for the Commission Representations Regarding European Documentation Centres' COMM/B.2/MH/ES (2007) 10815.

viii Overy and Mayfield (nvi).

ix Letter to the Department of Printed Books, Bodleian Library, from J. Leymarie, Secretary of the Working Party on Publications Distribution Policy of the European Communities, 28/11/1963.

${ }^{x}$ Ian Thomson, writing in 1990 did not include the Bodleian as one of the depository libraries: 'Overall, in the United Kingdom there are four depository libraries as opposed to 44 EDCs.' The four were the Liverpool and Westminster public libraries, the British Library/Document Supply Service and the British Library, Reference Division in London.' Thomson (niii).

xi This trend was noted by Bell and Watson in 2004: Maria Bell and Margaret Watson, 'European Documentation Centres: Providing Researchers with a Way through the Maze' (2009) 9 Legal Information Management 104.
} 
xii Under the current agreement, the host structure undertakes to 'place a qualified librarian or other professional with a diploma in documentation or information studies in charge of the organisation and operation of the EDC'. According to Richard Caddel, writing in 1997, the agreement that was signed by vice chancellors in 1995 stipulated that a 'full-time qualified librarian' be placed in charge of the collection. Caddel (nii) (emphasis added).

xiii Under CILIP's 'Ethical Principles and Code of Professional Practice for Library and Information Professionals' (2004), one of the principles that should characterise the conduct of members is 'Impartiality, and avoidance of inappropriate bias, in acquiring and evaluating information and in mediating it to other information users.' . https://www.cilip.org.uk/research/topics/ethics-review/existing-ethical-framework Accessed 04/07/2017.

xiv Cyril Emery, 'The Democratic Function of EDC Librarian's (2008) Focus: News and Views from the European Information Association (8) 1. Available at SSRN: https://ssrn.com/abstract=2051305 Accessed 02/07/2017 